DOI: $10.36910 / 6775-2524-0560-2019-37-12$

УДК: 602.1:519.85:53.082.9:616-07

${ }^{1}$ Марценюк В. П., ${ }^{2}$ Сверстюк А. С., ${ }^{3}$ Козодій Н. В., ${ }^{4}$ Дзядевич С. В., ${ }^{2}$ Стравський Т. Я.

${ }^{1}$ Університет в Бельсько Бяла

${ }^{2}$ Тернопільський національний медичний університет імені І.Я. Горбачевського,

${ }^{3}$ Тернопільський національний технічний університет імені Івана Пулюя,

${ }^{4}$ Інститут молекулярної біології і генетики НАН України,

\title{
ФУНКЦІОНАЛЬНІ ОСОБЛИВОСТІ БІОСЕНСОРІВ ТА ЇХ МОДЕЛЮВАННЯ
}

Марценюк В. П., Сверстюк А. С., Козодій Н. В., Дзядевич С. В., Стравський Т. Я. Функціональні особливості біосенсорів та їх моделювання. В роботі описано принцип роботи, основні елементи конструкції, галузі застосування та перспективи розвитку біосенсорів. Розглянуто підходи до їх розробки, наведені основні аналітичні характеристики, функціональні схеми вимірювання за допомогою біосенсора. Розглянуто проблеми і перспектива розвитку біосенсорів. Розроблено математичну модель біосенсора на основі гексагональної решітки 3 використанням решітчастих диференціальних рівнянь.

Ключові слова: біосенсори, математична модель, чисельне моделювання

Марценюк В. П., Сверстюк А. С., Козодий Н. В., Дзядевич С. В., Стравський Т. Я. Функциональные особенности биосенсоров и их моделирования. В работе описан принцип работы, основные элементы конструкции, области применения и перспективы развития биосенсоров. Рассмотрены подходы к их разработке, приведены основные аналитические характеристики, функциональные схемы измерения с помощью биосенсора. Рассмотрены проблемы и перспективы развития биосенсоров. Разработана математическая модель биосенсора на основе гексагональной решетки с использованием решетчатых дифференциальных уравнений.

Ключевые слова: биосенсоры, математическая модель, численное моделирование

Martseniuk V. P., Sverstiuk A. S., Kozodiy N. V., Dzadevich S. V., Stravsky T. Y. Functional features of biosensors and their modeling. The paper describes the principle of operation, the basic elements of design, scope and prospects for the development of biosensors. Approaches to their development are considered, basic analytical characteristics, functional circuits of measurement with biosensor are presented. The problems and perspective of biosensors development are considered. A mathematical model of biosensor based on hexagonal lattice using lattice differential equations is developed.

Keywords: biosensors, mathematical model, numerical modeling

Постановка наукової проблеми. Виявлення патогенних організмів, гормонів та інших відповідних аналітів вимагає створення інноваційних аналітичних приладів 3 підвищеною чутливістю, селективністю, високою точністю та швидкістю вимірювання, які базуються на різних фізичних явищах. Існуючі точні та чутливі лабораторні методи вимірювання, як правило, вимагають громіздкого і дорогого вимірювального обладнання, довготривалу підготовку досліджуваного зразка та наявність висококваліфікованого персоналу для обслуговування такого обладнання.

Аналіз досліджень. Актуальним напрямком розвитку аналітичного приладобудування $\epsilon$ створення мініатюрних вимірювальних засобів. Мініатюризація пристроїв може бути досягнута за допомогою технології «лабораторії на чіпі» (lab on chip - LOC), яка об’єднує кілька вимірювальних функцій в одному чутливому елементі приладу. Ця технологія використовує мініатюрні вимірювальні об'єми для обробки малої дози аналіту. Перспективність такої концепції розвитку аналітичних приладів та переваги LOC систем забезпечується зниженням проби досліджуваної речовини і витрат реагентів, автоматизацією та високою швидкістю отримання результату [1]. Основним елементом конструкції аналітичних приладів, які побудовані за технологією LOC, яка визначає характеристики приладу, $є$ сенсор. Відповідно до загальновизнаної термінології, сенсор - це чутливий елемент аналітичного датчика та фізичний перетворювач (первинний перетворювач), що реагує на зміну складу аналізованого компонента (аналіту) чи параметра, функціонально зв'язаного 3 ним [2]. Хімічний сенсор складається 3 чутливого шару, що селективно реагує на визначений аналіт за допомогою хімічної реакції, та фізичного перетворювача, який перетворює процес хімічної реакції в електричний сигнал та може бути використаний для якісного чи кількісного визначення цього аналіту [3]. Термін хімічний сенсор включає також і біологічні сенсори, що відрізняються від хімічних сенсорів наявністю на чутливому шарі біологічно активної речовини (рецептору), яка відповідає за селективність сенсора при аналізі взаємодій між біологічними об'єктами. Найбільш яскравими представниками біологічних сенсорів, які поєднують в собі перераховані якості, $є$ біосенсори.

За допомогою біосенсорів проводять швидкі і прості вимірювання широкого кола речовин 3 високою селективністю та точністю [4]. Біосенсори характеризуються високою ефективністю і широко використовуються у харчовій промисловості [5], при моніторингу навколишнього середовища [6], в оборонній промисловості [7], але найчастіше за все у медичній діагностиці [8-14]. 
Основна частина. Біосенсори - різновид хімічних сенсорів, в яких система розпізнавання має біологічну природу та використовує або індивідуальні біомолекули, або біологічні надмолекулярні структури [15].

Під терміном біосенсор розуміють пристрій, в якому чутливий шар містить біологічний матеріал: ферменти, тканини, бактерії, дріжджі, антигени/антитіла, ліпосоми, органели, рецептори, ДНК. Цей шар безпосередньо реагує на присутність певного компоненту і генерує сигнал, що залежить від концентрації цього компонента.

Конструктивно біосенсор аналогічний іншим видам хімічних сенсорів і складається із двох перетворювачів (біохімічного і фізичного), які знаходяться у тісному контакті один з одним [16].

При цьому біохімічний перетворювач (біотрансдьюсер), виконує функцію біологічного елементу розпівнавання, перетворюючи компоненти, що визначаються, а точніше, інформацію про хімічні зв'язки у фізичні або хімічні властивості, в електричний сигнал. Фізичний перетворювач дає змогу зареєструвати цей сигнал.

Принцип роботи біосенсорів. Наявність у біосенсорі відповідних біоматеріалів з унікальними властивостями дозволяє з високою селективністю визначити необхідні сполуки у складній за складом суміші, не вдаючись до додаткових операцій, пов'язаних з використанням інших реагентів.

У якості трансдьюсерів можуть бути використані різні біосенсори: електрохімічні, оптичні, термічні, п’єзоелектричні, на поверхневих акустичних хвилях тощо.

Біошар (біологічний елемент розпізнавання) може складатися із цілих організмів, живих тканин, клітин, органел, мембран, ферментів (індивідуальних), препаратів ферментів (неочищених), рецепторів, антитіл, нуклеїнових кислот тощо. Принцип роботи заснований на найважливіших хімічних реакціях живих організмів: реакції антитіло/антиген, фермент/субстрат, рецептор/гормон. Такі реакції використовуються для отримання високоселективних i чутливих біосенсорів, за допомогою яких визначаються необхідні речовини. У біосенсорах чутлива макромолекула, зазвичай, іммобілізована всередині мембрани або хімічно пов'язана з поверхнею, яка контактує з розчином речовини, що визначається. Функціональна схема біосенсора зображена на рис. 1.

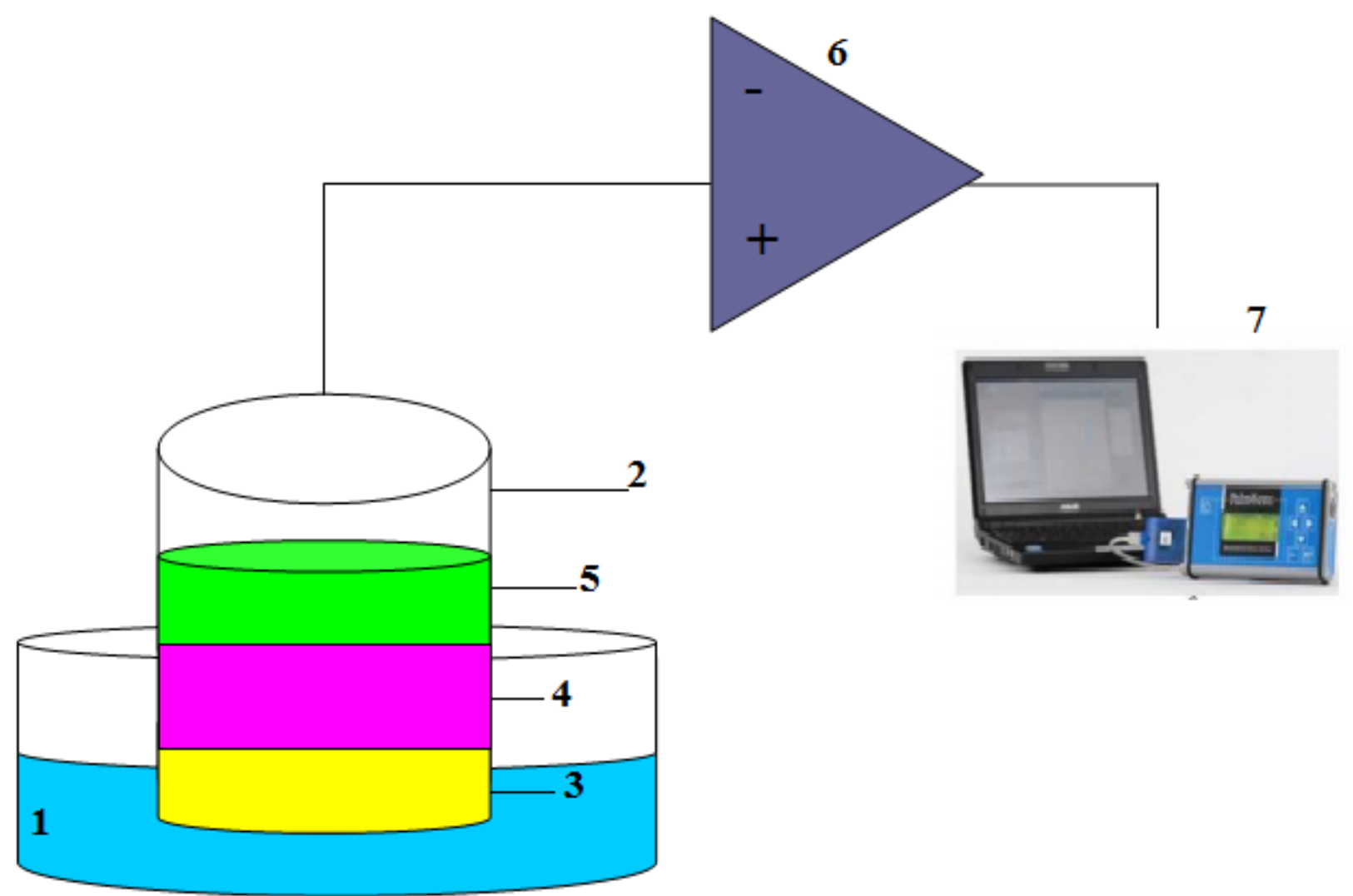

1 - досліджувальний розчин;

2 - корпус біосенсора;

3 - напівпроникна мембрана (для механічного утримання біошару); 
4 - шар біоматеріалу;

5 - фізичний перетворювач електрод, п’єзокристал і т.д.;

6 - підсилювач сигналу;

7 - пристрій відображення вимірювальної величини.

Рис.1. Функиіональна схема біосенсора.

Речовина, що визначається, дифундує через напівпроникну мембрану в тонкий шар біокаталізатора, в якому і протікає ферментативна реакція (рис. 1). Оскільки в даному випадку продукт ферментативної реакції визначається за допомогою електрода, на поверхні якого закріплений фермент, то такий пристрій називають ферментним електродом.

Між реагентом і речовиною, що визначається, завжди відбувається специфічна хімічна реакція. Це може бути або прямою взаємодією реагенту з речовиною, яка визначається, як у випадку реакції антиген/антитіло, або каталітичною взаємодією іммобілізованного ферменту з речовиною, що легко утворюється з продукту, що визначається [16].

Основні аналітичні характеристики біосенсора. Ефективність біосенсора визначають його аналітичні характеристики:

1. Селективність - це найважливіша характеристика біосенсора, що вказує на його здатність відрізняти одну речовину від інших. Селективність визначається розпізнавальним елементом сенсора, хоча в ряді випадків на неї впливають і характеристики трансдьюсера.

2. Граниия визначення (чутливість) - найменша концентрація, що може бути визначена біосенсором. Як правило, чутливість сенсора повинна бути нижчою за 1 ммоль, але в деяких випадках вона може досягати декількох фемтомолів $\left(10^{-15}\right.$ моль $)$.

3. Точність. Біосенсор повинен забезпечувати точність вимірювань, тобто результати, що одержується повинні бути близькими до істинного значення.

4. Biдтворюваність - це міра того, як повторюються результати при багаторазовому проведенні вимірювань одним способом, а точність характеризує правильність отриманих результатів.

5. Природа розчину. Характеристики біосенсора можуть змінюватися залежно від $\mathrm{pH}$, температури та іонної сили розчину.

6. Час відгуку - це той час, який потрібен для того, щоб аналітична система або прилад прийшли до стану рівноваги зі сполукою, що визначається. Звичайно в біосенсорах час відгуку становить понад 30 с, що значно більше, ніж у хімічних сенсорів.

7. Час регенерації - це час, необхідний для повернення сенсора у початковий стан, коли його знову можна використовувати для вимірювання.

8. Термін експлуатаиії сенсора - визначається стабільністю розпізнавального елемента. Для біосенсорів він може становити від декількох днів до місяців.

На рисунку 2 наведена функціональна схема вимірювання за допомогою біосенсора.

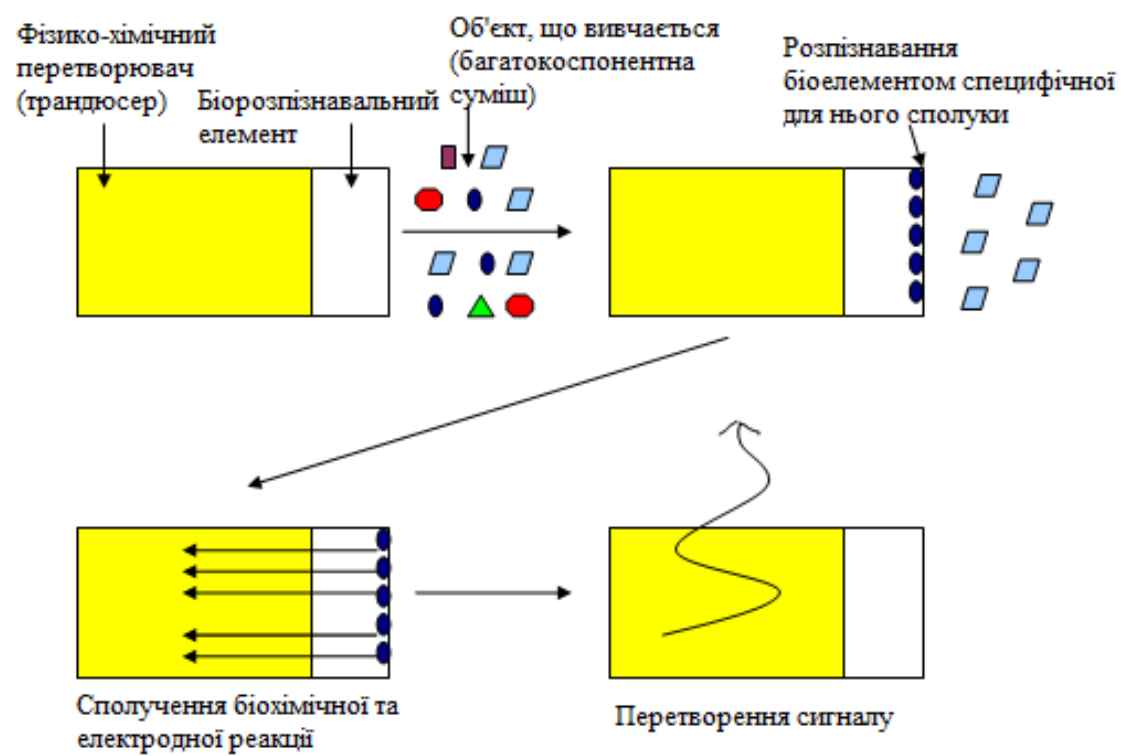

Рис. 2. Функиіональна схема вимірювання за допомогою біосенсора. 
Біосенсор складається 3 двох елементів: перетворювача (трансдьюсера) і біорозпізнавального елемента.

На першому етапі вимірювання за допомогою біосенсора відбувається «ропізнавання» біоелементом специфічної для нього речовини з багатокомпонентної суміші.

На другому етапі відбувається перетворення інформації про протікання біохімічної реакції в електричний сигнал (електрохімічний, оптичний та ін.).

На останньому етапі електричний сигнал від трансдьюсора перетворюється в цифрову форму 3 метою візуалізації (рис. 2).

Проблеми і перспектива розвитку біосенсорів. Головна перевага біосенсорів - висока специфічність біомолекул до цільового субстрату. Окремим класом біосенсорів є біосенсори, які отримали розвиток в останні роки. Біосенсори — це клас біосенсорів, пов'язаний із застосуванням антитіл як елементів біочутливості. Реакція відбувається між цільовою аналізованою речовиною та специфічним антитілом [17]. Електрохемілюмінісценція — біодосліджувана система для виявлення тринітроетилену, при якому антитіла, мічені до ензиму, фіксовані на парамагнітних носіях, сконцентровані на електроді завдяки магнетизму [18]. Проводяться дослідження 3 метою використання компактних мембран для біологічних досліджень [19]. Слід зазначити, що, незважаючи на успіхи біологічних досліджень, є труднощі: необхідні специфічні антитіли до кожної сполуки; біосенсори мають високу вартість; важко розрізняти сигнали при застосуванні біосенсорів; можлива втрата чутливості до них. До негативних моментів слід також віднести матричні ефекти, неспецифічну взаємодію, гетерогенність. Таким чином, створення біосенсорів та їх використання сприяють розвитку науки i промисловості. Сфера їх застосування різноманітна, включаючи моніторування навколишнього середовища. Фундаментальною основою біосенсорів стало визначення антигенів антитілами завдяки утворенню стабільного компоненту. Водночас необхідне підвищення їх специфічності та розпізнавальної здатності. Цей метод не може бути застосований поки що у виробництві, а застосовується тільки в лабораторних дослідженнях. Маючи характеристики трасдукторів, біосенсори істотно малі, але активно проводяться спроби понизити їх розмір для більш ефективного застосування і для експериментів in vitro i in vivo. Це необхідно для досягнення певного фізичного стану, а не для сенсорів взагалі. Перспективи застосування біосенсорів розширяються, більшість досліджень пов'язані з розробками чутливих до медикаментів сенсорів та діагностикою різних захворювань [20, 21]. Відомі біосенсори, що можуть контролювати кількість глюкози [22], лактату [23], гормонів [24] у біологічних середовищах. Більшість цих завдань об'єднуються, узагальнюються, деякі з них пов'язані 3 молекулярними відбитками, матеріалами санітарії і гігієни, особливістю дії лікарських препаратів [25]. Аптамери можуть бути селективними елементами біосенсорів до спор Bacillus antracis, вірусу Influenza, збудників туляреміï, трипаносомозу, сальмонельозу, деяких інших збудників інфекційних хвороб [26]. Тому дослідження в цьому напрямку будуть розвиватися і далі. Встановлено, що сигнали внутрішньоклітинного кальцію можуть бути отримані in vivo. На сьогодні вже визначені метаболітотропні рецептори до катіонів, а також розшифровано процес вивільнення кальцію з внутрішньоклітинних депо [27]. Це перспективний напрямок для створення біосенсорів лікарських засобів, які впливають на обмін кальцію. Роботи в напрямку пошуків біосенсорів, дослідження їх властивостей, застосування в медичній практиці будуть сприяти підвищенню діагностики та ефективного лікування різних захворювань.

\section{Математична модель біосенсора}

Математична модель біосенсора на основі гексагональної решітки має вигляд решітчастої системи диференціальних рівнянь із запізненням

$$
\begin{aligned}
& \frac{d V_{i, j, k}(t)}{d t}=\left(\beta-\gamma F_{i, j, k}(t-\tau)\right)-\delta_{\nu} V_{i, j, k}(t-\tau) V_{i, j, k}(t)+\hat{S}\left\{V_{i, j, k}\right\} \\
& \frac{d F_{i, j, k}(t)}{d t}=\left(-\mu_{f}+\eta \gamma V_{i, j, k}(t-\tau)-\delta_{f} F_{i, j, k}(t) F_{i, j, k}(t)\right) F_{i, j, k}(t)
\end{aligned}
$$

яка задана початковими функціями (2):

$$
\begin{aligned}
& V_{i, j, k}(t)=V_{i, j, k}^{0}(t) \geq 0, \\
& F_{i, j, k}(t)=F_{i, j, k}^{0}(t) \geq 0, \quad t \in[-\tau, 0), \\
& V_{i, j, k}(0), \quad F_{i, j, k}(0)>0 .
\end{aligned}
$$

У формулах (1)-(2) використано наступні позначення: 
$F_{i, j, k}(t)$ - концентрація антитіл в біопікселі;

$V_{i, j, k}(t)$ - концентрація антигенів;

$i, j, k$ - координати біопікселів;

$\hat{S}$ - просторовий оператор дифузії між сусідніми пікселями;

$\gamma$ - ймовірністна швидкість нейтралізації антигенів антитілами;

$\Delta$ - відстань між пікселями;

$\delta_{f}$ - швидкість, 3 якою популяція антитіл прагне до деякої межі насичення;

$\delta_{v}$ - швидкість, з якою популяція антигенів прагне до деякої межі насичення;

$\eta \gamma$ - ймовірнісна швидкість імунної відповіді на збільшення щільності антигенів;

$\mu_{f}$ - постійна смертності антитіл;

$\tau$ - постійна запізнення в часі, з якою настає імунна відповідь.

Модель (1) використовує просторовий оператор $\hat{S}\left\{V_{i, j, k}\right\}$ :

$$
\hat{S}\left\{V_{i, j, k}\right\}=\left\{\begin{array}{c}
D \Delta^{-2}\left[V_{i+1, j, k-1}+V_{i+1, j-1, k}+V_{i, j-1, k+1}+V_{i-1, j, k+1}+V_{i-1, j+1, k}+V_{i, j+1, k-1}-6 n V_{i, j, k}\right], \\
i, j, k \in \overline{-N+1, N-1}, \quad i+j+k=0 .
\end{array}\right.
$$

\section{Результати чисельного моделювання}

Чисельні експерименти на основі комп'ютерного моделювання проводилися із врахуванням цілого натурального числа $N$, яке характеризує кількість пікселів в гексагональній решітці. Розглянемо

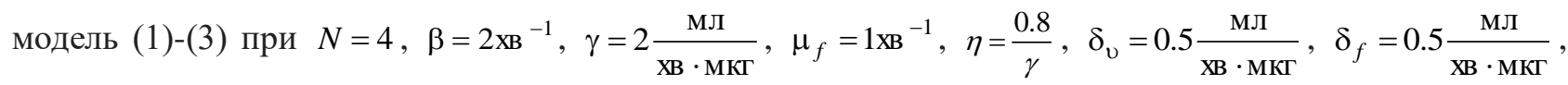
$n=0.9, \quad D=0.2, \Delta=0.3$. Комп'ютерне моделювання було реалізовано для різних значень $\tau$. Результати чисельного моделювання системи (1) у вигляді фазових діаграм наведено на рис.1.

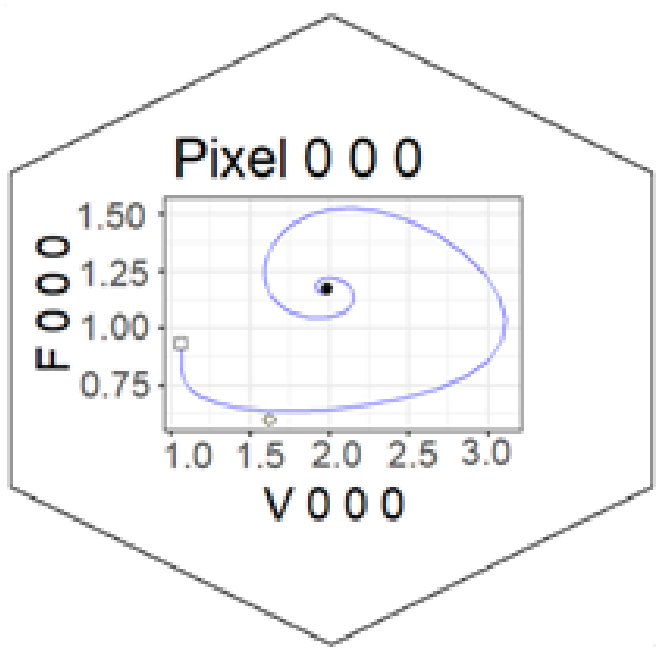

a)

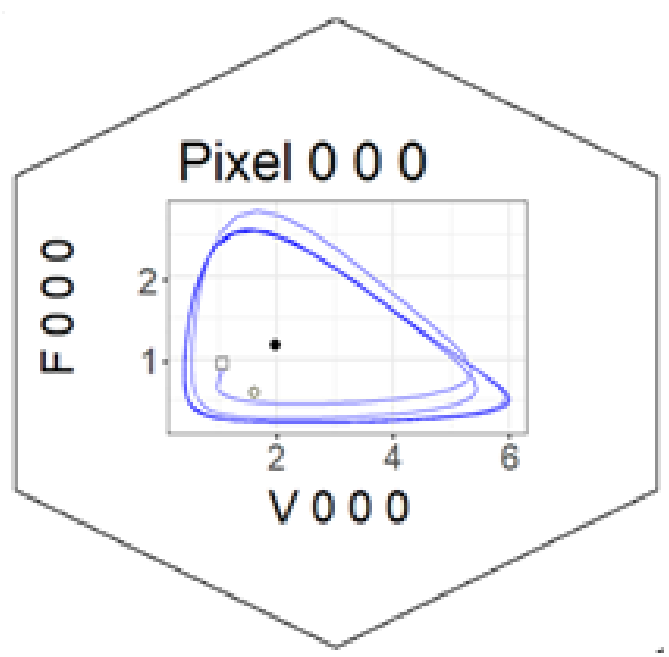

б)

Рисунок 1. Результати чисельного моделювання системи (1) при а $-\tau=0.05, \sigma-\tau=0.25$.

Аналізуючи фазові діаграми популяцій антигенів щодо антитіл (рис. 1) можна зробити висновок, що при $\tau=0,05$ розв'язок системи (1) прагне до неідентичного ендемічного стану, який в даному випадку є стійким фокусом. Такі залежності спостерігаються для всіх біопікселів кібер-фізичної моделі біосенсорної системи на гексагональній решітці 3 використанням решітчастих диференціальних рівнянь із запізненням при $\tau \in[0,0.25$ ) (рис. $3 \mathrm{a}$ ).

Аналізуючи фазові діаграми популяцій антигенів щодо антитіл (рис. 3б) можна зробити висновок, що при $\tau=0,25$ виникає біфуркація Хопфа. Для теоретичного обгрунтування виникнення біфуркації Хопфа необхідно обчислити відповідну пару чисто уявних розв'язків характеристичного рівняння 
лінеаризованої системи (1). Результати чисельного моделювання узгоджені 3 теоретичними результатами на основі теореми про біфуркацію Хопфа. При цьому розв'язок системи (1) прагне до стійкого граничного циклу з двома локальними екстремумами (один локальний максимум і один локальний мінімум) в циклі.

\section{Висновки та перспективи подалыших досліджень.}

В останні десятиліття проводяться дослідження з розробки методів і сенсорів, які можуть бути застосовані практично в будь-якому місці як експрес метод діагностики в клінічній медицині. Найкраще для цієї мети підходять портативні, швидкі і чутливі біосенсорні технології з можливістю оперативної інтерпретації результатів вимірювання медико-біологічних параметрів. Біосенсори та біосенсори, завдяки їх високій специфічності та чутливості, дають змогу виявляти широкий спектр аналітів в зразках зі складною матрицею (слина, кров, сироватка, лімфа, сеча), забезпечуючи при цьому мінімальну пробопідготовку.

Отже, в подальших дослідженнях доцільно розробляти математичні моделі біосенсорів та методи дослідження їх стійкості, з можливістю використання отриманих результатів при проектуванні сучасних вимірювальних систем медико-біологічних параметрів

\section{Список бібліографічного опису.}

1. Марценюк В.П. Про принципи, методи та сфери медико-біологічного застосування оптичних імуносенсорів [Текст] / В. П. Марценюк, А. Клос-Вітковська, А. С. Сверстюк, Т. В. Бігуняк // Медична інформатика та інженерія. 2018. № 2 (42). С. 28-36.

2. Амер Абдулмахді Члайхаві, Сепер Емаміан, Біну Бебі Наракату, Мохаммед Мохаммед Алі, Дінеш Маддіпатла, Бредлі Дж. Базуін, Массуд 3. Аташбар, екранований і гнучкий п'єзоелектричний датчик змінного струму на основі змінного струму, датчики та приводи A: фізичний, Том 268, 2017, Стор. 1-8, ISSN 0924-4247, https://doi.org/10.1016/j.sna.2017.10.030.

3. Aurélie Bouchet-Spinelli, Bertrand Reuillard, Liliane Coche-Guérente, Sylvie Armand, Pierre Labbé, Sébastien Fort, олігосахаридний біосенсор для прямого моніторингу ферментативної діяльності з використанням QCM-D, Biosensors and Bioelectronics, том 49, 2013, стор. 290-296, ISSN 0956-5663, https://doi.org/10.1016/j.bios.2013.05.027.

4. Габріела Фігероа-Міранда, Лінгян Фен, Саймон Чи-Чин Шиу, Родерік Маршалл Діркцвагер, Йе-Вай Чен, Джуліан Олександр Таннер, Майкл Йозеф Шенінг, Андреас Офенхауссер, Дірк Майер, електрохімічний біосенсор на основі Аптамера для високочутливої та селективної малярії виявлення з регульованим діапазоном динамічного реагування та повторним використання, Датчики та пускачі В: Хімічна, Том 255, Частина 1, 2018, Сторінки 235-243, ISSN 0925-4005, https://doi.org/10.1016/j.snb.2017.07. 117.

5. Man Lv, Yang Liu, Jinhui Geng, Xiaohong Kou, Zhihong Xin, Dayong Yang, інженерні біосенсори на основі наноматеріалів для виявлення безпеки харчових продуктів, біосенсори та біоелектроніка, том 106, 2018, стор. 122-128, ISSN 0956-5663, https : //doi.org/10.1016/j.bios.2018.01.049.

6. Майкл Швенк, агенти хімічної війни. Класи та цілі, Токсикологічні листи, Том 293,2018, Сторінки 253-263, ISSN 03784274, https://doi.org/10.1016/j.toxlet.2017.11.040.

7. Томаш Кутні, Міхал Крчма, Йозеф Когут, Петро Єзек, Яна Варнускова, Петро Вчелак, Ян Стрнадек, Он-лайн обчислення рівня глюкози в крові, Інформатика про Prodia, Том 98, 2016, Сторінки 228-235, ISSN 1877-0509, https://doi.org/10.1016/j.procs.2016.09.037.

8. Х'ю Хендрі, Менджі Чжен, Вей Лі, Кетлін Лейн, Роберта Амбуел, Крістіана Пурнелл, Фредерік Унверзагт, Алексія Торке, Ашок Баласубраманям, Кріс М. Каллахан, Суджуан Гао, зниження рівня глюкози передує деменції у літніх афроамериканців $з$ діабетом, хвороба Альцгеймера та деменція, том 13, випуск 2, 2017, сторінки 111-118, ISSN 15525260, https://doi.org/10.1016/j.jalz.2016.08.017.

9. Фуміхіто Накано, Кен Сакусіма, Реона Умекі, Ічіро Ябе, Акіра Ендох, Хіденао Сасакі, Вплив віку та рівня глюкози на рівень лактату в обстеженні спинномозкової рідини нейродегенеративних захворювань, Журнал неврологічних наук, том 378, 2017, Сторінки 45 -48, ISSN 0022-510X, https://doi.org/10.1016/j.jns.2017.04.033.

10. IJsbrand T. Klip, Douwe Postmus, Adriaan A. Voors, Frank PJ Brouwers, Ron T. Gansevoort, Stephan JL Bakker, Hans L. Hillege, Rudolf A. de Boer, Pim van der Harst, Wiek H. van Gilst, Дірк Дж. Ван Велдхуазен, Пітер ван дер Меер, Рівень гемоглобіну та серцева недостатність у новому стані, American Heart Journal, том 169, випуск 1, 2015, Сторінки 94 101.e2, ISSN 0002-8703, https: / /doi.org/10.1016/j.ahj.2014.09.010.

11. Трентон Хонда, Вівіан Ч. Пун, Джастін Манджуридес, Хелен Сух, поширеність анемії та рівень гемоглобіну пов'язані 3 тривалим впливом забруднення повітря у літніх людей, Екологічний Інтернешнл, Том 101, 2017, Сторінки 125-132, ISSN 0160-4120, https://doi.org/10.1016/j.envint.2017.01.017.

12. Ліза Дж. Форест, Комп'ютерна томографія в онкології, Ветеринарні клініки Північної Америки: практика для малих тварин, том 46, випуск 3, 2016, Сторінки 499-513, ISSN 0195-5616, ISBN 9780323444880, https: // doi. org / 10.1016 / j.cvsm.2015.12.007.

13. Чженмінг Гу, Хайцин Чжу, Алісія Родрігес, Мохаммед Мейссен, Стейсі Шульц Черрі, Елізабет Аддерсон, Рендалл Т. Хейден, Порівняльна оцінка широкопанельних ПЛР-аналізів для виявлення шлунково-кишкових патогенів у дитячих онкологічних пацієнтів, Журнал молекулярної діагностики , Том 17, Випуск 6, 2015, Сторінки 715-721, ISSN 1525-1578, https://doi.org/10.1016/j.jmoldx.2015.06.003.

14. Акіфумі Кавамура, Такаші Міята, 4.2 - Біосенсори, Редактор: Міцухіро Ебара, Біоматеріали Наноархітектоніка, Видавництво Ендрю Ендрю, 2016, Сторінки 157-176, ISBN 9780323371278, https://doi.org/10.1016/B978-0 -323-371278.00010-8.

15. Марценюк В. П., Клос-Вітковська А., Сверстюк А.С. Вивчення класифікації імуносенсорів $з$ точки зору медичних завдань // Медична інформатика та інженерія. - 2018.-№ 1 (41). - С.13-19. 
16. Чен-Схін Чуанг, Ii-Чун Ду, Тин-Фен Ву, Чен-Хо Чен, Да-Хуей Лі, Ши-Мін Чен, Тін-Чи Хуанг, Ссун-Пей Ву, Мухаммед Омар Шайх, Імуносензор для надчутливих та кількісне виявлення раку сечового міхура в точці тестування на догляд, Біосенсори та біоелектроніка, Том 84, 2016, Сторінки 126-132, ISSN 0956-5663, https: //

\section{References}

1. Martsenyuk V.P. On principles, methods and areas of medical and biological application of optical immunosensors [Text] / V. P. Martsenyuk, A. Klos-Witkowska, A. S. Sverstiuk, T. V. Bihunyak // Medical informatics and engineering. 2018. № 2 (42). P. 28-36.

2. Amer Abdulmahdi Chlaihawi, Sepehr Emamian, Binu Baby Narakathu, Mohammed Mohammed Ali, Dinesh Maddipatla, Bradley J. Bazuin, Massood Z. Atashbar, A screen printed and flexible piezoelectric-based AC magnetic field sensor, Sensors and Actuators A: Physical, Volume 268, 2017, Pages 1-8, ISSN 0924-4247, https://doi.org/10.1016/j.sna.2017.10.030.

3. Aurélie Bouchet-Spinelli, Bertrand Reuillard, Liliane Coche-Guérente, Sylvie Armand, Pierre Labbé, Sébastien Fort, Oligosaccharide biosensor for direct monitoring of enzymatic activities using QCM-D, Biosensors and Bioelectronics, Volume 49, 2013, Pages 290-296, ISSN 0956-5663, https://doi.org/10.1016/j.bios.2013.05.027.

4. Gabriela Figueroa-Miranda, Lingyan Feng, Simon Chi-Chin Shiu, Roderick Marshall Dirkzwager, Yee-Wai Cheung, Julian Alexander Tanner, Michael Josef Schöning, Andreas Offenhäusser, Dirk Mayer, Aptamer-based electrochemical biosensor for highly sensitive and selective malaria detection with adjustable dynamic response range and reusability, Sensors and Actuators B: Chemical, Volume 255, Part 1, 2018, Pages 235-243, ISSN 0925-4005, https://doi.org/10.1016/j.snb.2017.07.117.

5. Man Lv, Yang Liu, Jinhui Geng, Xiaohong Kou, Zhihong Xin, Dayong Yang, Engineering nanomaterials-based biosensors for food safety detection, Biosensors and Bioelectronics, Volume 106, 2018, Pages 122-128, ISSN 0956-5663, https://doi.org/10.1016/j.bios.2018.01.049.

6. Michael Schwenk, Chemical warfare agents. Classes and targets, Toxicology Letters, Volume 293,2018, Pages 253-263, ISSN 0378-4274, https://doi.org/10.1016/j.toxlet.2017.11.040.

7. Tomas Koutny, Michal Krcma, Josef Kohout, Petr Jezek, Jana Varnuskova, Petr Vcelak, Jan Strnadek, On-line Blood Glucose Level Calculation, Procedia Computer Science, Volume 98, 2016,Pages 228-235, ISSN 1877-0509, https://doi.org/10.1016/j.procs.2016.09.037.

8. Hugh C. Hendrie, Mengjie Zheng, Wei Li, Kathleen Lane, Roberta Ambuehl, Christianna Purnell, Frederick W. Unverzagt, Alexia Torke, Ashok Balasubramanyam, Chris M. Callahan, Sujuan Gao, Glucose level decline precedes dementia in elderly African Americans with diabetes, Alzheimer's \& Dementia, Volume 13, Issue 2, 2017, Pages 111-118, ISSN 1552-5260, https://doi.org/10.1016/j.jalz.2016.08.017.

9. Fumihito Nakano, Ken Sakushima, Reona Umeki, Ichiro Yabe, Akira Endoh, Hidenao Sasaki, Effects of age and glucose levels on lactate levels in cerebrospinal fluid examination of neurodegenerative diseases, Journal of the Neurological Sciences, Volume 378, 2017, Pages 45-48, ISSN 0022-510X, https://doi.org/10.1016/j.jns.2017.04.033.

10. IJsbrand T. Klip, Douwe Postmus, Adriaan A. Voors, Frank P.J. Brouwers, Ron T. Gansevoort, Stephan J.L. Bakker, Hans L. Hillege, Rudolf A. de Boer, Pim van der Harst, Wiek H. van Gilst, Dirk J. van Veldhuisen, Peter van der Meer, Hemoglobin levels and new-onset heart failure in the community, American Heart Journal, Volume 169, Issue 1, 2015, Pages 94-101.e2, ISSN 0002-8703, https://doi.org/10.1016/j.ahj.2014.09.010.

11. Trenton Honda, Vivian C. Pun, Justin Manjourides, Helen Suh, Anemia prevalence and hemoglobin levels are associated with long-term exposure to air pollution in an older population, Environment International, Volume 101, 2017, Pages 125-132, ISSN 0160-4120, https://doi.org/10.1016/j.envint.2017.01.017.

12. Lisa J. Forrest, Computed Tomography Imaging in Oncology, Veterinary Clinics of North America: Small Animal Practice, Volume 46, Issue 3, 2016, Pages 499-513, ISSN 0195-5616, ISBN 9780323444880, https://doi.org/10.1016/j.cvsm.2015.12.007.

13. Zhengming Gu, Haiqing Zhu, Alicia Rodriguez, Mohammad Mhaissen, Stacey Schultz Cherry, Elisabeth Adderson, Randall T. Hayden, Comparative Evaluation of Broad-Panel PCR Assays for the Detection of Gastrointestinal Pathogens in Pediatric Oncology Patients, The Journal of Molecular Diagnostics, Volume 17, Issue 6, 2015, Pages 715-721, ISSN 1525-1578, https://doi.org/10.1016/j.jmoldx.2015.06.003.

14. Akifumi Kawamura, Takashi Miyata, 4.2 - Biosensors, Editor(s): Mitsuhiro Ebara, Biomaterials Nanoarchitectonics, William Andrew Publishing, 2016, Pages 157-176, ISBN 9780323371278, https://doi.org/10.1016/B978-0-323-37127-8.00010-8.

15. Martsenyuk V.P., Klos-Witkowska A., Sverstiuk A.S. Study of classification of immunosensors from viewpoint of medical tasks // Medical informatics and engineering. - 2018.-№ 1(41). - p.13-19.

16. Cheng-Hsin Chuang, Yi-Chun Du, Ting-Feng Wu, Cheng-Ho Chen, Da-Huei Lee, Shih-Min Chen, Ting-Chi Huang, Hsun-Pei $\mathrm{Wu}$, Muhammad Omar Shaikh, Immunosensor for the ultrasensitive and quantitative detection of bladder cancer in point of care testing, Biosensors and Bioelectronics, Volume 84, 2016, Pages 126-132, ISSN 0956-5663, https://doi.org/10.1016/j.bios.2015.12.103.

17. Parthasarathy P, Vivekanandan S, A numerical modelling of an amperometric-enzymatic based uric acid biosensor for GOUT arthritis diseases, Informatics in Medicine Unlocked, 2018, ISSN 2352-9148, https://doi.org/10.1016/j.imu.2018.03.001.

18. Fernando Zanghelini, Isaac A.M. Frías, Moacyr J.B.M. Rêgo, Maira G.R. Pitta, Marco Sacilloti, Maria D.L. Oliveira, Cesar A.S. Andrade, Biosensing breast cancer cells based on a three-dimensional TIO2 nanomembrane transducer, Biosensors and Bioelectronics, Volume 92, 2017, Pages 313-320, ISSN 0956-5663, https://doi.org/10.1016/j.bios.2016.11.006.

19. X. Jiang, M. G. Spencer "Electrochemical impedance biosensor with electrode pixels for precise counting of CD4+ cells: A microchip for quantitative diagnosis of HIV infec- tion status of AIDS patients," Biosensors and Bioelectronics, vol. 25, no. 7, pp. 1622-1628, Mar. 2010. Agata Rembielak, Melanie Green, Azeem Saleem, Pat Price, Diagnostic and therapeutic imaging in oncology, Medicine, Volume 44, Issue 1, 2016, Pages 6-9, ISSN 1357-3039, https://doi.org/10.1016/j.mpmed.2015.10.010.

20. Alexandra M.V. Wennberg, Adam P. Spira, Corinne Pettigrew, Anja Soldan, Vadim Zipunnikov, George W. Rebok, Allen D. Roses, Michael W. Lutz, Michael M. Miller, Madhav Thambisetty, Marilyn S. Albert, Blood glucose levels and cortical thinning in cognitively normal, middle-aged adults, Journal of the Neurological Sciences, Volume 365, 2016, Pages 89-95, ISSN 0022510X, https://doi.org/10.1016/j.jns.2016.04.017.

21. Sarah H. Kagan, The Future of Gero-Oncology Nursing, Seminars in Oncology Nursing, Volume 32, Issue 1, 2016, Pages 65-76, ISSN 0749-2081, https://doi.org/10.1016/j.soncn.2015.11.008. 
22. Gennady A. Evtugyn, Rezeda V. Shamagsumova, Tibor Hianik, 2 - Biosensors for detection mycotoxins and pathogenic bacteria in food, Editor(s): Alexandru Mihai Grumezescu, Nanobiosensors, Academic Press, 2017, Pages 35-92, ISBN 9780128043011 , https://doi.org/10.1016/B978-0-12-804301-1.00002-3.

23. Electrochemical and optical biosensors based on nanomaterials and nanostructures: a review. Front. Biosci. (Schol Ed) 3:13081331. doi:10.2741/228.

24. Wang, B., Takahashi, S., Du, X., and Anzai, J. (2014). Electrochemical biosensors based on ferroceneboronic acid and its derivatives: a review. Biosensors (Basel) 4, 243-256. doi:10.3390/bios4030243.

25. Dias, A. D., Kingsley, D. M., and Corr, D. T. (2014). Recent advances in bioprinting and applications for biosensing. Biosensors (Basel) 4, 111-136. doi:10.3390/ bios4020111.

26. Alireza Nezami, Sadegh Dehghani, Rahim Nosrati, Negar Eskandari, Seyed Mohammad Taghdisi, Gholamreza Karimi. Nanomaterial-based biosensors and immunosensors for quantitative determination of cardiac troponins / Journal of Pharmaceutical and Biomedical Analysis. - Vol. 159. - 2018. - P. 425-436.

27. Oldach, L., and Zhang, J. (2014). Genetically encoded fluorescent biosensors for live-cell visualization of protein phosphorylation. Chem. Biol. 21, 186-197. doi:10.1016/j.chembiol.2013.12.012. 